\title{
Analisis Kinerja Struktur Bangunan Rumah Tinggal dengan Kayu Glulam Mahoni
}

\author{
Nessa Valiantine Diredja ${ }^{1}$, Erma Desmaliana ${ }^{2}$, Raca Prasetyo ${ }^{3}$ \\ Jurusan Teknik Sipil, Fakultas Teknik Sipil dan Perencanaan, ITENAS, Bandung \\ Email: nessa.valiantine@itenas.ac.id
}

\begin{abstract}
ABSTRAK
Rumah merupakan salah satu bangunan gedung yang harus memenuhi persyaratan keselamatan. Untuk memenuhi persyaratan keselamatan tersebut maka dalam perancangannya perlu mengikuti pedoman dan standar yang berlaku. Penelitian ini menganalisis kinerja struktur bangunan rumah tinggal kayu glulam dari kayu Mahoni berdasarkan Standar Nasional Indonesia (SNI) 7973:2013 dan Eurocode menggunakan program SAP2000. Dari hasil preliminary design didapatkan dimensi balok dengan ukuran $170 \times 340 \mathrm{~mm}$ dan kolom berukuran $300 \times 400 \mathrm{~mm}$ untuk SNI dan balok berukuran 270mm x 550 serta kolom berukuran $450 \times 600 \mathrm{~mm}$ untuk Eurocode. Hasil analisis program SAP2000 menunjukan bahwa kinerja struktur kedua bangunan telah memenuhi syarat ketahanan gempa yaitu perioda struktur, simpangan ijin, dan nilai minimum ragam alami struktur. Berdasarkan hasil analisis non-linier pushover didapatkan bahwa bangunan rumah tinggal termasuk dalam kategori tingkat kinerja Damage Control untuk SNI, sedangkan bangunan rumah tinggal berdasarkan Eurocode termasuk kedalam kategori tingkat kinerja Immediate Occupancy.
\end{abstract}

Kata Kunci: Kayu glulam, Mahoni, SNI 7973:2013, Eurocode, Kinerja Struktur

\begin{abstract}
Basically a house is a building that must meet safety requirements. To meet these safety requirements, in its design it is necessary to follow applicable guidelines and standards. This study analyse the structure performance of glulam residential building from Mahogany wood based on Indonesian National Standard (SNI) 7973:2013 and Eurocode using SAP2000 Program. Based on preliminary design, different dimensions of structural elements are obtained, which is beam size $170 \times 340 \mathrm{~mm}$ and column size $300 \times 400 \mathrm{~mm}$ for SNI and beam size $270 \times 550 \mathrm{~mm}$ and column size $450 \times 600 \mathrm{~mm}$ for Eurocode. SAP2000 program analysis showed that the performance of the structures of two building has met the earthquake resistance requirements such as period of structure, story drift and minimum value of modal participation ratio. Based on the result of nonlinear pushover analysis, the SNI residential building were included in the Damage Control Performance level category, while Eurocode residential building were included in the category of Immediate Occupancy performance level.
\end{abstract}

Keywords: Glulam wood, Mahony, SNI 7973:2013, Eurocode, Level of Performance 


\section{PENDAHULUAN}

Bangunan rumah tinggal dengan menggunakan material kayu merupakan hal yang umum di Indonesia, namun material ini memiliki beberapa keterbatasan, antara lain dimensinya yang terbatas dan jika tidak dirawat dengan baik maka material ini akan mudah mengalami kerusakan. Untuk memenuhi ketersediaan akan kebutuhan material kayu, telah dikembangkan suatu material rekayasa yaitu komponen laminasi yang dibuat melalui perekatan atau biasa disebut sebagai Glulam (Glued Laminated). Balok laminasi merupakan salah satu produk kayu rekayasa tertua. Balok laminasi terbuat dari dua atau lebih kayu gergajian yang direkatkan dengan arah sejajar serat satu sama lain, berbentuk lurus atau lengkung tergantung peruntukannya (Moody et al. 1999).

Menurut Bodiq dan Jayne prinsip desain laminasi adalah memaksimalkan dimensi dengan meminimalkan material. Apabila prinsip dapat dilakukan secara simultan maka tujuan penggunaan laminasi dapat dicapai secara maksimal, sehingga laminasi merupakan desain ekonomis dengan tetap memenuhi prinsip struktural (Bodiq dan Jayne, 2003).

Keuntungan balok laminasi menurut Serrano (2003) dapat meningkatkan sifat-sifat kekuatan dan kekakuan, memberikan pilihan bentuk geometri yang lebih beragam, memungkinkan untuk penyesuaian kualitas laminasi dengan tegangan yang diinginkan serta meningkatkan akurasi dimensi dan stabilitas bentuk.

Dalam perencanaan bangunan gedung, persyaratan keselamatan adalah hal utama yang harus dipenuhi. Pada penelitian sebelumnya yaitu penelitian Afandi (2010) dilakukan analisis seismik struktur pada bangunan dengan materia beton bertulang. Untuk itu pada penelitian ini dilakukan suatu analisis untuk mengetahui perbandingan kinerja struktur rumah tinggal dengan menggunakan kayu glulam berdasarkan SNI 7973:2013 dan Eurocode.

\section{TINJAUAN PUSTAKA}

\subsection{Kayu Glulam Struktural Pada SNI 7973:2013}

Terminologi kayu glulam struktural mengacu pada rekayasa teknik, produk pemilahan tegangan dari kilang laminasi kayu, meliputi perakitan dari kayu laminasi yang dipilih dan dipersiapkan secara khusus dan digabung menggunakan perekat. Serat seluruh laminasi kira-kira sejajar serat dalam arah longitudinal. (SNI 7973:2013).

\subsubsection{Nilai Desain Acuan Terkoreksi}

Nilai desain acuan $\left(F_{b}, F_{t}, F_{v}, F_{c \perp}, F_{c}, F_{v t}, E, E_{m \min }\right)$ harus dikalikan dengan faktor koreksi yang ditetapkan pada Tabel 1 untuk menentukan nilai desain terkoreksi $\left(\mathrm{F}_{\mathrm{b}}, F_{b}{ }^{b}, F_{\mathrm{t}}{ }^{x}, F_{V}{ }^{g}, F_{c \perp}{ }^{b}, F_{c}{ }^{g}\right.$, $\left.F_{\text {vit }}{ }^{\prime}, E^{s}, E_{\text {min }}{ }^{g}\right)$. 
Tabel 1. Penggunaan Faktor Koreksi dari Kayu Glulam Struktural

\begin{tabular}{|c|c|c|c|c|c|c|c|c|c|c|c|c|c|c|}
\hline & \multirow{3}{*}{ 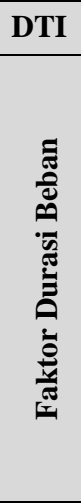 } & \multirow{3}{*}{ 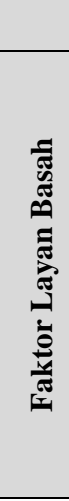 } & \multirow{3}{*}{ 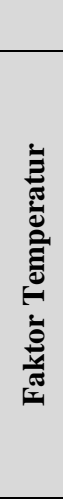 } & \multirow{3}{*}{ 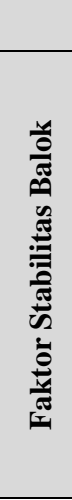 } & \multicolumn{4}{|c|}{ DTI dan DFBK } & \multirow{3}{*}{ 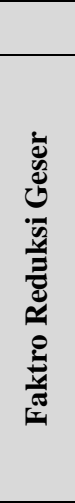 } & \multirow{3}{*}{ 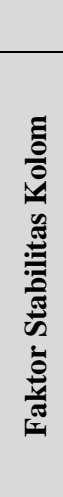 } & \multirow{3}{*}{ 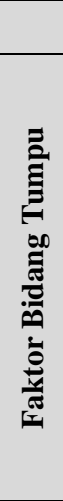 } & \multicolumn{3}{|c|}{ DFBK } \\
\hline & & & & & 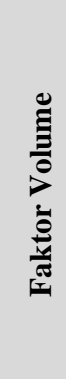 & 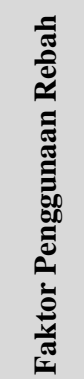 & 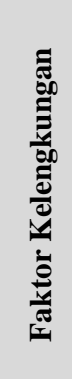 & 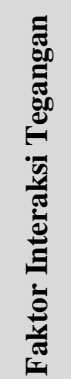 & & & & 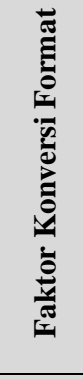 & 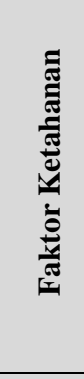 & 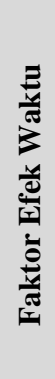 \\
\hline & & & & & & & & & & & & $K_{f}$ & $\phi_{b}$ & \\
\hline$F_{b}{ }^{b}=F_{b} \times$ & $C_{D}$ & $C_{M}$ & $C_{\mathrm{t}}$ & $C_{L}$ & $C_{V}$ & $C_{f u}$ & $C_{c}$ & $C_{I}$ & - & - & - & 2,54 & 0,85 & $\lambda$ \\
\hline$F_{\mathrm{t}}{ }^{\theta}=F_{\mathrm{t}} \times$ & $C_{D}$ & $C_{M}$ & $C_{\mathrm{t}}$ & - & - & - & - & - & - & - & - & 2,70 & 0,80 & $\lambda$ \\
\hline$F_{D}{ }^{g}=F_{D} \times$ & $C_{D}$ & $C_{M}$ & $C_{t}$ & - & - & - & - & - & $C_{\text {Vt }}$ & - & - & 2,88 & 0,75 & $\lambda$ \\
\hline$F_{r t}{ }^{o}=F_{r t} \times$ & $C_{D}$ & $C_{M}$ & $C_{\mathrm{t}}$ & - & - & - & - & - & - & - & - & 2,88 & 0,75 & $\lambda$ \\
\hline$F_{c}^{\prime}=F_{c} \times$ & $C_{D}$ & $C_{M}$ & $C_{\mathrm{t}}$ & - & - & - & - & - & - & $C_{P}$ & - & 2,40 & 0,90 & $\lambda$ \\
\hline$F_{c \perp}{ }^{b}=F_{c \perp} \times$ & - & $C_{M}$ & $C_{\mathrm{t}}$ & - & - & - & - & - & - & - & $C_{b}$ & 1,67 & 0,90 & $\lambda$ \\
\hline$E^{\prime}=E \times$ & - & $C_{M}$ & $C_{\mathrm{t}}$ & - & - & - & - & - & - & - & - & - & - & - \\
\hline$E_{\min }{ }^{\prime \prime}=E_{\min } \times$ & - & $C_{M}$ & $C_{\mathrm{t}}$ & - & - & - & - & - & - & - & - & 1,76 & 0,85 & - \\
\hline
\end{tabular}

\subsection{Eurocode 5: Design of Timber Structures}

Eurocode 5: Design of Timber Structures merupakan pedoman yang menjelaskan cara merancang bangunan dan pekerjaan teknik sipil dengan material kayu yang menggunakan filosofi Load And Resistance Factor Design (LRFD).

\subsubsection{Perilaku Mekanik Kayu Glulam}

Kekuatan mekanik kayu glulam dapat ditentukan berdasarkan kekuatan kayu aslinya dengan mengikuti persamaan berdasarkan BS EN 1194:1999 pada Tabel 2.

Tabel 2. Persamaan Konversi Kekuatan Properti Kayu Solid ke Glulam

\begin{tabular}{|c|c|c|}
\hline Properti [MPa] & \multicolumn{2}{|c|}{ Persamaan Koversi } \\
\hline Bending & $f_{m, g k}$ & $=7+1,15 f_{t, 0, \mu k}$ \\
\hline \multirow[t]{2}{*}{ Tension } & $f_{t, 0, k}$ & $=5+0,8 f_{t, 0, l k}$ \\
\hline & $f_{t, 90, g, k}$ & $=0,2+0,015 f_{t, 0,1, k}$ \\
\hline \multirow[t]{2}{*}{ Compresion } & $f_{c, 0, g k}$ & $=7,2 f_{t, 0,1 / k}^{0,45}$ \\
\hline & $f_{e, 90, g, k}$ & $=0,7 f_{t, 0,1 k}^{0,5}$ \\
\hline Shear & $f_{V, g k}$ & $=0,32 f_{\mathrm{t}, 0, \mathrm{l} k \mathrm{k}}^{0.8}$ \\
\hline \multirow[t]{3}{*}{ Modulus of elasticity } & $E_{0, \text { gmean }}$ & $=1,05 E_{0 \text {. Imean }}$ \\
\hline & $E_{0,9,0.05}$ & $=0,85 E_{0,1 \text { mean }}$ \\
\hline & $E_{90 \text { gmean }}$ & $=0,035 E_{0, \text { mean }}$ \\
\hline Shear Modulus & $G_{g \text { mean }}$ & $=0,065 E_{0,1 \text { mean }}$ \\
\hline Density & $P_{g, k}$ & $=1,10 \rho_{g i l}$ \\
\hline
\end{tabular}




\subsubsection{Verifikasi dengan Metode Faktor Parsial}

Nilai desain sifat kekuatan, $X_{\mathscr{L}}$, harus dihitung seperti pada Persamaan 1

$$
X_{d}=k_{\text {mod }} \frac{x_{k}}{\gamma_{M}}
$$

halmana:

$X_{d} \quad=$ nilai karakteristik sifat kekuatan,

$\gamma_{M} \quad=$ faktor parsial untuk properti material,

$k_{\text {mod }}=$ faktor modifikasi dengan mempertimbangkan efek dari durasi beban dan kelembaban.

\subsection{Pembebanan untuk Bangunan Rumah Tinggal SNI}

Pembebanan dilakukan berdasarkan SNI 1726:2012, SNI 1727:2013 dan Peraturan Pembebanan untuk Gedung 1983, dengan beban yang bekerja pada struktur adalah beban mati (DL), beban hidup ( $L L)$, beban mati tambahan (SDL), dan beban gempa (EQ).

\subsection{Pembebanan untuk Bangunan Rumah Tinggal Eurocode}

Pembebanan berdasarkan Eurocode 1: Action on Structure. Beban pada gedung diberikan oleh beberapa aksi (action) yaitu Permanent action (G), Variable action (Q), dan Accidental action (A).

\subsection{Kategori Risiko dan Faktor Keutamaan Gempa}

Berdasarkan SNI 1726:2012, jenis pemanfaatan bangunan gedung untuk fungsi perumahan mempunyai kategori risiko II dan faktor keutamaan gempa $\left(I_{\epsilon}\right)$ adalah 1,0 .

\subsection{Pemilihan Sistem Struktur}

Penelitian ini menggunakan sistem struktur rangka kayu dengan koefisien modifikasi respon $(R)$ adalah 1,5 dan Faktor pembesaran defleksi $\left(C_{d}\right)$ adalah 1,5.

\subsection{Simpangan Antar Lantai}

Berdasarkan SNI 1726:2012 nilai simpangan antar lantai izin harus lebih besar dari selisih defleksi terbesar antar lantai. Persamaan defleksi pusat massa dapat dilihat pada Persamaan 2

$$
\delta_{x}=\frac{c_{d} \varepsilon_{x x}}{I_{x}}
$$

halmana:

$\delta_{x}=$ simpangan antar lantai $[\mathrm{mm}]$,

$C_{d}=$ faktor pembesaran defleksi,

$\delta_{x e}=$ perpindahan maksimum pada lokasi lantai yang ditinjau [mm],

$I_{e} \quad=$ faktor keutamaan gempa.

Simpangan antar lantai ijin menurut SNI 1726:2012 untuk struktur rangka kayu dan kategori risiko II, dapat dilihat pada Persamaan 3.

$$
\Delta_{i j i n}=0,025 \times h_{s x}
$$

halmana:

$\Delta_{i j i n}=$ simpangan antar lantai ijin [mm],

$h_{s x} \quad=$ ketinggian setiap lantai $[\mathrm{mm}]$. 


\subsection{Respons Spektrum}

Data respons spektrum yang digunakan dalam perencanaan gempa didapatkan dengan mengakses website online Pusat Penelitian dan Pengembangan Permukiman. Diperoleh data nilai spektral percepatan untuk tanah sedang di Bandung seperti yang terlihat pada Tabel 3.

Tabel 3. Nilai Spektral Percepatan untuk Tanah Sedang di Bandung

\begin{tabular}{cccc}
\hline Variabel & Nilai & Variabel & Nilai \\
\hline$P G A[\mathrm{~mm}]$ & 0,577 & $P S A[\mathrm{~g}]$ & 0,577 \\
\hline$S_{g}[\mathrm{~mm}]$ & 1,450 & $S_{M S}[\mathrm{~g}]$ & 1,450 \\
\hline$S_{1}[\mathrm{~mm}]$ & 0,486 & $S_{M I}[\mathrm{~g}]$ & 0,486 \\
\hline$C_{R S}$ & 0,977 & $S_{D S}[\mathrm{~g}]$ & 0,967 \\
\hline$C_{R I}$ & 0,905 & $S_{D 1}[\mathrm{~g}]$ & 0,324 \\
\hline$F_{P G A}$ & 1 & $T_{0}[$ detik] & 0,067 \\
\hline$F_{A}$ & 1 & $T_{S}[$ detik] & 0,335 \\
\hline \multicolumn{2}{c}{$F_{V}$} & 1 &
\end{tabular}

(Sumber: http://puskim.pu.go.id/Aplikasi/desain_spektra_indonesia_2011/)

\subsection{Modal Partisipasi Massa}

Berdasarkan SNI 1726:2012 nilai analisis harus menyertakan jumlah ragam yang cukup untuk mendapatkan partisipasi massa ragam terkombinasi sebesar paling sedikit $90 \%$ dari massa aktual dalam masing-masing arah horizontal orthogonal dari respon yang ditinjau oleh model.

\subsection{Analisis Statik Beban Dorong (Static Pushover Analysis)}

Analisis Statik Beban Dorong (Static Pushover Analysis) adalah suatu analisis statik non-linier, yang dalam analisisnya pengaruh gempa rencana terhadap struktur bangunan gedung dianggap sebagai beban statik pada pusat massa masing-masing lantai, yang nilainya ditingkatkan secara berangsur-angsur sampai melampaui pembebanan sehingga menyebabkan terjadinya pelelehan (sendi plastis) pertama di dalam struktur bangunan gedung, kemudian dengan peningkatan beban lebih lanjut mengalami perubahan bentuk pasca-elastik yang besar sampai target peralihan yang diharapkan atau sampai mencapai kondisi plastis (Pranata, Y. A., Simanta, D., 2006)

\subsection{Kurva Kapasitas (Capacity Curve)}

Kurva kapasitas hasil dari analisis statik beban dorong menunjukkan hubungan antara gaya geser dasar dan perpindahan atap akibat beban lateral yang diberikan pada struktur.

\subsection{Tingkat Kinerja}

Titik kinerja merupakan titik pertemuan kurva demand dengan kurva kapasitas yang digunakan untuk memeriksa apakah komponen struktural dan non-struktural tidak melebihi batas kerusakan yang diizinkan. 


\section{METODE PENELITIAN}

Penelitian ini terdiri dari beberapa kegiatan yang ditunjukkan pada bagan alir penelitian seperti pada Gambar 1.
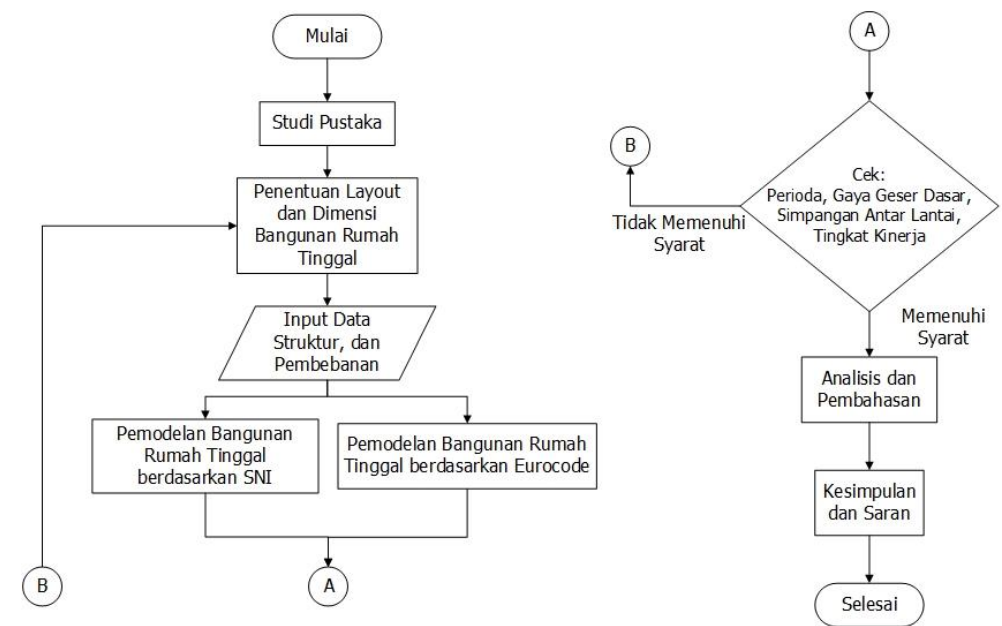

Gambar 1. Bagan Alir

\subsection{Penentuan Layout dan Dimensi Bangunan Rumah Tinggal}

Desain layout bangunan rumah tinggal yang digunakan dalam penelitian ini adalah sebagai berikut:

1. Lokasi bangunan berada di Kota Bandung.

2. Fungsi bangunan adalah rumah tinggal.

3. Bangunan memiliki panjang $12 \mathrm{~m}$, lebar $8 \mathrm{~m}$, dan terdiri dari 3 (tiga) lantai termasuk atap dengan tinggi antar lantai sebesar $3,7 \mathrm{~m}$.

4. Denah bangunan dapat dilihat pada Gambar 2.a dan Gambar 2.b.

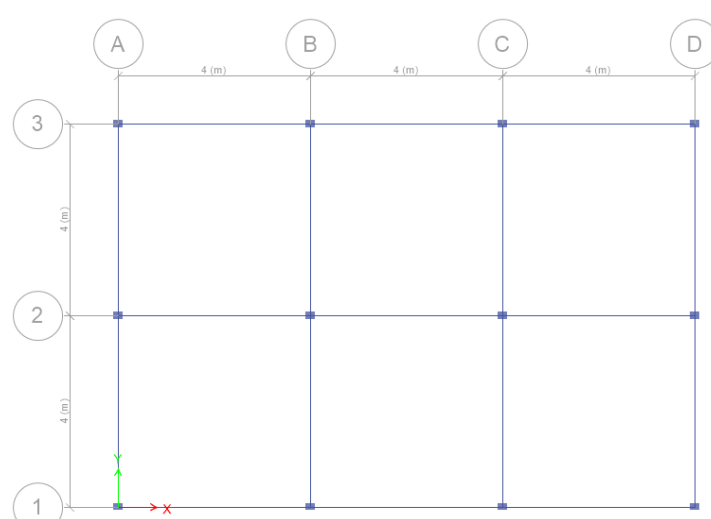

Gambar 2.a Denah lantai 1-2

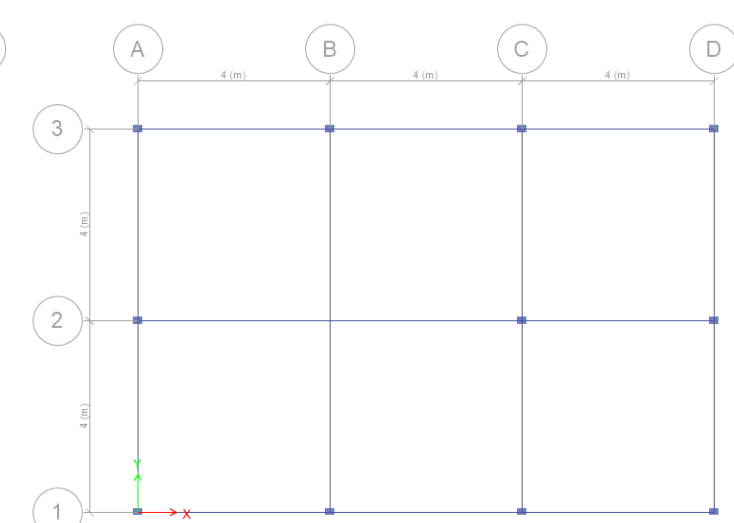

Gambar 2.b Denah lantai 3

\subsection{Pendefinisian Data dan Pembebanan}

Pembebanan yang diberikan pada gedung sesuai dengan SNI 1726:2012, SNI 1727:2013 dan Peraturan Pembebanan untuk Gedung 1983. Data lainnya adalah material kayu asli yang digunakan adalah mahoni dengan sifat kekuatan dalam kondisi kering udara dan berat jenis 0,63 dapat dilihat pada Tabel 4. 
Tabel 4. Sifat Kekuatan Kayu Mahoni

\begin{tabular}{lcc}
\hline Sifat Kekuatan Kayu & Besaran & Satuan \\
\hline Kuat Lentur Pada Beban Ultimit & 623 & {$\left[\frac{\mathrm{kg}}{\mathrm{cm}^{2}}\right]$} \\
\hline Modulus Elastisitas & $92 * 10^{3}$ & {$\left[\frac{\mathrm{kg}}{\mathrm{cm}^{2}}\right]$} \\
\hline Kuat Tekan Sejajar Serat & 360 & {$\left[\frac{\mathrm{kg}}{\mathrm{cm}^{2}}\right]$} \\
\hline Kuat Tarik (Tangensial) & 47,8 & {$\left[\frac{\mathrm{kg}}{\mathrm{cm}^{2}}\right]$} \\
\hline Kuat Geser & 42,2 & {$\left[\frac{\mathrm{kg}}{\mathrm{cm}^{2}}\right]$} \\
\hline
\end{tabular}

(Sumber: Mardikanto, 2010)

Data perencanaan struktur lainnya yang akan digunakan dalam penelitian ini adalah sebagai berikut:

1. Dengan data desain spektral percepatan wilayah Bandung dengan tanah sedang, maka:
a) Kategori desain seismik
: $\quad$ (menurut SNI 1726:2012).
b) Faktor redundansi, $\rho$
: 1,3 (menurut SNI 1726:2012).
c) Koefisien batas atas perioda, $C_{u}$
: 1,424 (menurut SNI 1726:2012).

2. Tipe struktur merupakan rangka kayu maka nilai parameter perioda pendekatan, $C_{t}=$ 0,0488 dan $x=0,75$ (menurut SNI 1726:2012)

3. Sifat kekuatan kayu glulam mahoni dapat dilihat seperti pada Tabel 5.

Tabel 5. Nilai Desain Acuan Kayu Glulam Mahoni

\begin{tabular}{|c|c|c|c|c|}
\hline \multirow{2}{*}{ Nilai Desain Acuan } & \multicolumn{2}{|c|}{ SNI } & \multicolumn{2}{|c|}{ Eurocode } \\
\hline & Simbol & [MPa] & Simbol & [MPa] \\
\hline Berat Jenis & G & 6,3 & $\rho$ & 6,710 \\
\hline Kuat Lentur // serat & $F_{b y}$ & 12,8 & \multirow{2}{*}{$f_{m, g}$} & \multirow{2}{*}{12,497} \\
\hline Kuat Lentur $\perp$ serat & $F_{b x}$ & 8,3 & & \\
\hline Kuat Tekan // serat & $F_{c}$ & 10,4 & $f_{t, 0, g, k}$ & 14,557 \\
\hline Kuat Geser & $F_{D}$ & 1,4 & $f_{D, g k}$ & 1,119 \\
\hline \multirow{2}{*}{ Modulus Elastisitas } & $E$ & 9.722 & $E_{0, g \text { mean }}$ & 9.660 \\
\hline & $E_{\min }$ & 5.069 & $E_{0}$ & 7.820 \\
\hline
\end{tabular}

\section{PEMODELAN STRUKTUR}

Dalam penelitian ini, dibuat 2 struktur yang dimodelkan dan ditinjau yaitu pemodelan berdasarkan SNI 7973:2013 dan berdasarkan Eurocode 5. Hasil preliminary design didapatkan elemen struktur seperti yang ditunjukkan pada Tabel 6, dan hasil pemodelan pada program SAP2000 seperti pada Gambar 3.

Tabel 6. Ukuran Penampang Elemen Struktur

\begin{tabular}{lccc}
\hline Standar Perencanaan & $\begin{array}{c}\text { Balok } \\
{[\mathbf{m m}]}\end{array}$ & $\begin{array}{c}\text { Kolom } \\
{[\mathbf{m m}]}\end{array}$ & $\begin{array}{c}\text { Pelat } \\
{[\mathbf{m m}]}\end{array}$ \\
\hline SNI 7973:2013 & $170 * 340$ & $300 * 400$ & 65 \\
\hline Eurocode 5 & $270 * 550$ & $450 * 600$ & 65 \\
\hline
\end{tabular}




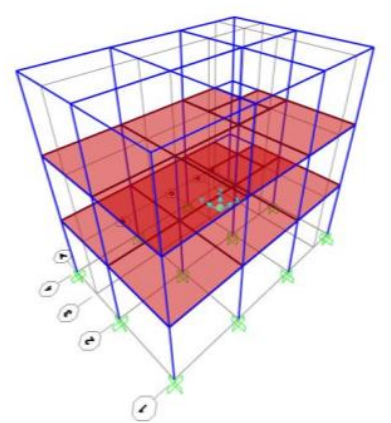

Gambar 3. Tampak 3D model bangunan rumah tinggal SNI dan Eurocode

\section{ANALISIS}

Dari hasil analisis modal pada Tabel 7 menunjukan perioda maksimum struktur untuk bangunan rumah tinggal SNI lebih besar daripada Eurocode dikarenakan dimensi elemen struktur Eurocode lebih besar daripada SNI yang mengakibatkan bangunan rumah tinggal Eurocode lebih kaku. Namun keduanya memenuhi syarat batas perioda yaitu kurang dari 0,422 detik.

Tabel 7. Perioda Struktur Bangunan Rumah Tinggal

\begin{tabular}{ccccc}
\hline Mode & \multicolumn{2}{c}{ Perioda [detik] } & $\begin{array}{c}\text { Batas } \\
\text { Perioda } \\
\text { [detik] }\end{array}$ & Keterangan \\
\cline { 2 - 4 } & SNI & Eurocode & 0,422 & OK \\
\hline 1 & 0,339 & 0,198 & 0,422 & OK \\
\hline
\end{tabular}

Dari hasil analisis struktur yang dapat dilihat pada Tabel 8 memperlihatkan bahwa kedua model bangunan rumah tinggal memenuhi syarat simpangan antar lantai ijin. Bangunan rumah tinggal SNI memiliki simpangan antar lantai lebih besar daripada bangunan rumah tinggal Eurocode dikarenakan dimensi elemen struktur Eurocode lebih besar yang mengakibatkan bangunan lebih kaku dan mengakibatkan simpangan yang lebih kecil.

Tabel 8. Simpangan Antar Lantai Bangunan Rumah Tinggal

\begin{tabular}{cccccc}
\hline \multirow{2}{*}{ Story } & Arah & \multicolumn{2}{c}{$\begin{array}{c}\text { Story Drift } \\
{[\mathbf{m m}]}\end{array}$} & $\begin{array}{c}\text { Simpangan antar } \\
\text { lantai ijin } \\
{[\mathbf{m m}]}\end{array}$ & Keterangan \\
\cline { 2 - 4 } & SNI & Eurocode & & OK \\
\hline 1 & $X$ & 10,403 & 4,082 & 92,5 & OK \\
\hline & $Y$ & 13,165 & 4,560 & 92,5 & OK \\
\hline 2 & $X$ & 22,376 & 7,293 & 92,5 & OK \\
\hline & $Y$ & 20,851 & 6,025 & 92,5 & OK \\
\hline 3 & $X$ & 20,639 & 6,976 & 92,5 & OK \\
\hline
\end{tabular}

Dari hasil analisis modal yang dapat dilihat pada Tabel 9 menunjukan bahwa kedua model bangunan rumah tinggal telah memenuhi syarat jumlah ragam getar pada masing-masing arah horizontal yaitu nilai ragam alami kedua model untuk masing-masing arah horizontal $>90 \%$. 
Tabel 9. Ragam Getar Bangunan Rumah Tinggal

\begin{tabular}{|c|c|c|c|c|c|c|}
\hline \multirow{3}{*}{ Mode } & \multicolumn{3}{|c|}{ SNI } & \multicolumn{3}{|c|}{ Eurocode } \\
\hline & Period & UX & UY & Period & UX & UY \\
\hline & [detik] & [\%] & [\%] & [\%] & [\%] & {$[\%]$} \\
\hline 1 & 0,339 & 86,410 & 0,000 & 0,198 & 86,540 & 0,000 \\
\hline 2 & 0,304 & 0,000 & 83,570 & 0,178 & 0,000 & 83,680 \\
\hline 3 & 0,284 & 0,000 & 0,020 & 0,169 & 0,010 & 0,210 \\
\hline 4 & 0,114 & 9,530 & 0,000 & 0,069 & 9,110 & 0,001 \\
\hline 5 & 0,106 & 0,000 & 6,470 & 0,066 & 0,000 & 4,970 \\
\hline 6 & 0,093 & 0,000 & 0,310 & 0,059 & 0,000 & 0,880 \\
\hline 7 & 0,090 & 1,620 & 0,010 & 0,056 & 1,770 & 0,005 \\
\hline 8 & 0,089 & 0,003 & 2,930 & 0,054 & 0,010 & 2,270 \\
\hline 9 & 0,083 & 0,000 & 3,070 & 0,052 & 0,000 & 4,210 \\
\hline 10 & 0,078 & 0,000 & 0,040 & 0,049 & 0,000 & 0,300 \\
\hline 11 & 0,069 & 2,430 & 0,000 & 0,041 & 2,560 & 0,000 \\
\hline 12 & 0,055 & 0,000 & 3,580 & 0,033 & 0,000 & 3,050 \\
\hline \multicolumn{2}{|c|}{ Jumlah } & 99,994 & 100,000 & Jumlah & 100,000 & 99,576 \\
\hline
\end{tabular}

Setelah dilakukan analisis pushover pada masing-masing model bangunan rumah tinggal SNI dan Eurocode menggunakan software SAP2000, didapatkan grafik dan hasil output hubungan kurva kapasitas dan kurva demand sesuai dengan parameter pushover analysis menurut ATC-40 Capacity Spectrum, dimana titik pertemuan antara kurva kapasitas dan kurva demand adalah titik kinerja struktur. Grafik hubungan antara kurva kapasitas dan kurva demand dapat dilihat pada Gambar 4 dan Gambar 5.

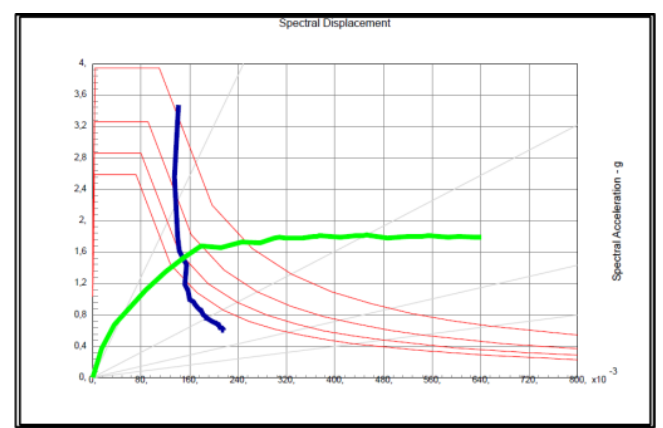

(a)

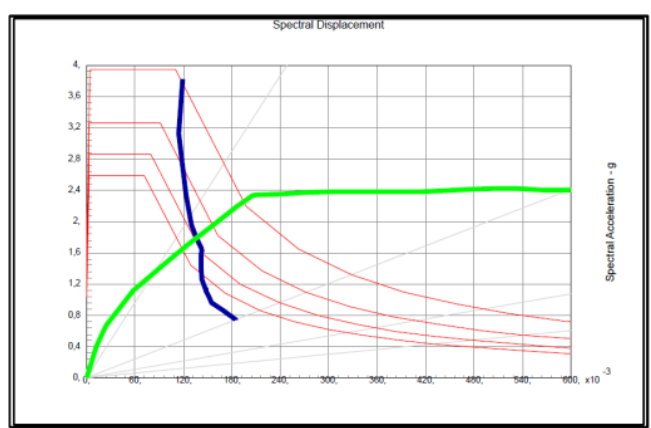

(b)

Gambar 4 Hubungan kurva kapasitas \& kurva demand bangunan rumah tinggal SNI arah-X (a) dan arah$\mathrm{Y}(\mathrm{b})$

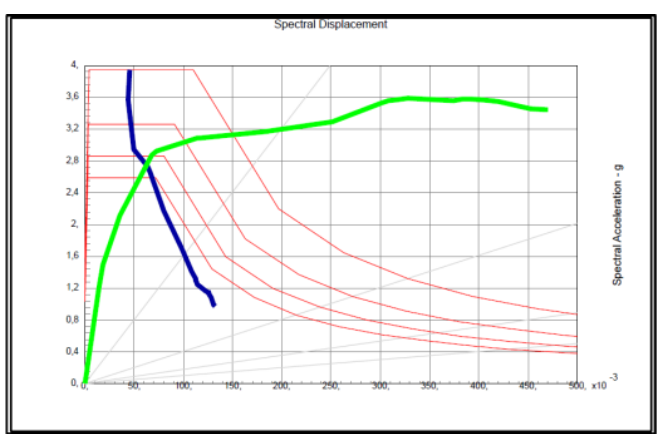

(a)

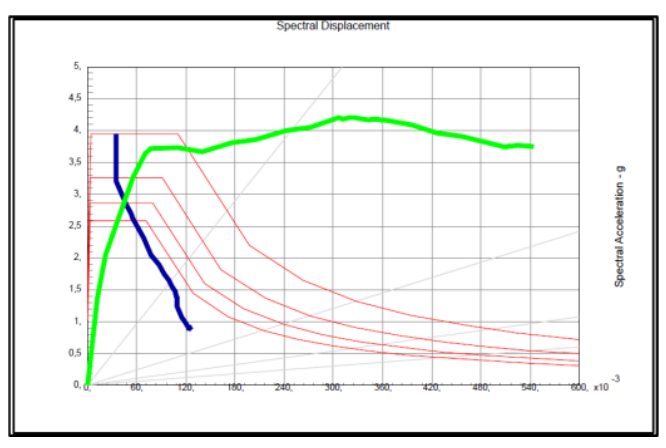

(b)

Gambar 5 Hubungan kurva kapasitas \& kurva demand bangunan rumah tinggal Eurocode arah-X (a) dan arah-Y (b) 


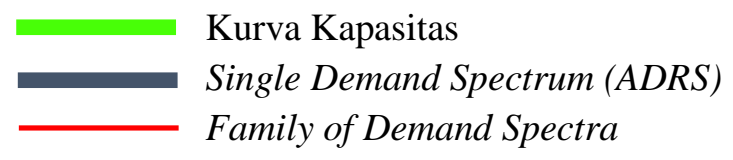

Dari hubungan kurva kapasitas dan kurva demand sesuai dengan parameter pushover analysis menurut ATC-40 Capacity Spectrum didapatkan data keluaran seperti pada Tabel 9.

Tabel 9. Titik Kinerja Bangunan Rumah Tinggal

\begin{tabular}{lcccc}
\hline \multirow{2}{*}{ Titik Kinerja } & \multicolumn{2}{c}{ SNI } & \multicolumn{2}{c}{ Eurocode } \\
\cline { 2 - 5 } & Arah X & Arah Y & Arah X & Arah Y \\
\hline Base Shear $[\mathrm{kN}]$ & 532,605 & 598,382 & $1.536,194$ & $1.549,600$ \\
\hline Displacement $[\mathrm{m}]$ & 0,220 & 0,219 & 0,083 & 0,060 \\
\hline Spectral Acceleration & 1,517 & 1,787 & 2,727 & 2,812 \\
\hline Spectral Displacement $[\mathrm{m}]$ & 0,149 & 0,136 & 0,061 & 0,043 \\
\hline Periode Efektif [detik] & 0,628 & 0,553 & 0,299 & 0,242 \\
\hline Ekivalen Viskositas Efektif & 0,158 & 0,158 & 0,166 & 0,138 \\
\hline
\end{tabular}

Maka berdasarkan ATC-40 bangunan rumah tinggal SNI termasuk dalam level kategori Damage Control yang berarti transisi antara Immediate Occupancy dan Life Safety. Lalu untuk bangunan rumah tinggal Eurocode termasuk dalam level kategori Immediate Occupancy dimana bila gempa terjadi, struktur mampu menahan gempa tersebut, struktur tidak mengalami kerusakan struktural dan tidak mengalami kerusakan non struktural.

Maka bangunan rumah tinggal kayu menggunakan glulam dari kayu mahoni dengan material properti kayu mahoni yang didapatkan dari data sekunder yang dirancang berdasarkan Eurocode 5: Design of Timber Structure memiliki tingkat kinerja yang lebih baik dibandingkan yang dirancang berdasarkan SNI 7973:2012 tentang spesifikasi desain untuk konstruksi kayu. Namun jika dinilai dari segi ekonomis, maka rumah tinggal kayu yang dirancang berdasarkan SNI 7973:2012 lebih ekonomis karena memiliki penampang elemen struktur yang lebih kecil

\subsection{Kesimpulan}

\section{KESIMPULAN DAN SARAN}

Dari hasil perhitungan dan analisis pada penelitian ini, dapat diambil kesimpulan sebagai berikut:

1. Perioda getar alami struktur bangunan rumah tinggal SNI untuk arah-x sebesar 0,339 detik dan arah-y sebesar 0,304 detik, sedangkan bangunan rumah tinggal Eurocode untuk arah-x sebesar 0,198 detik dan arah-y sebesar 0,178 detik. Perioda getar alami struktur bangunan rumah tinggal SNI lebih besar daripada bangunan rumah tinggal Eurocode dikarenakan dimensi elemen struktur Eurocode lebih besar daripada SNI yang mengakibatkan bangunan rumah tinggal Eurocode lebih kaku.

2. Rata-rata simpangan antar lantai untuk bangunan rumah tinggal SNI arah-x adalah sebesar 17,806 mm dan 16,855 mm pada arah-y untuk bangunan rumah tinggal Eurocode simpangan arah-x sebesar 6,117 mm dan arah-y sebesar 5,185 mm.

3. Hasil static pushover analysis didapatkan bahwa untuk bangunan rumah tinggal SNI termasuk dalam level kategori Damage Control yang berarti transisi antara Immediate 
Occupancy dan Life Safety, sedangkan untuk bangunan rumah tinggal Eurocode termasuk dalam level kategori Immediate Occupancy.

\subsection{Saran}

1. Dilakukan penelitian pada bangunan bukan rumah tinggal dengan jumlah lantai lebih dari 2.

2. Dilakukan analisis tambahan pada sambungan kayu.

\section{DAFTAR RUJUKAN}

[1] Afandi, N. R. (2010). Evaluasi Kinerja Seismik Struktur Beton dengan Analisis Pushover Menggunakan Program SAP 2000. Surakarta: Universitas Sebelas Maret.

[2] ATC 40. (1996). Seismic Evaluation and Retrofit of Concrete Buildings Volume 1. Applied Technology Council. California.

[3] Badan Standar Nasional. (2013). SNI 7973-2013 Spesifikasi Desain untuk Konstruksi Kayu. Jakarta: Departemen Pekerjaan Umum.

[4] Badan Standar Nasional. (2012). SNI 1726-2012 Standar Perencanaan Ketahanan Gempa untuk Struktur Bangunan Gedung dan Non Gedung. Jakarta: Departemen Pekerjaan Umum.

[5] Badan Standar Nasional. (2013). SNI 1727-2013 Beban Minimum untuk Perancangan Bangunan Gedung dan Struktur lain. Jakarta: Departemen Pekerjaan Umum.

[6] Bodiq, J., Jayne, B.A. (2003). Mechanics of Wood and Wood Composites, New York: Van Nostrand Reinhold Company, Hal: 335.

[7] British Standard. (1999). Timber Structure Glued Laminated Timber - Strength Classes and Determination of Characteristic Values. English: British Standard

[8] Commission of the European Communities. (2004). Eurocode No. 5: Design of timber structures - Part 1-1: General - Common rules and rules for buildings. English.

[9] Commission of the European Communities. (2002). Eurocode 1: Actions on structures Part 1-1: General actions -Densities, self-weight, imposed loads for buildings. English.

[10] Mardikanto TR, Karlinasari L, Bahtiar ET. (2011). Sifat Mekanis Kayu. Bogor. IPB Press.

[11] Moody RC, Hernandez R, Liu JY. (1999). Wood Handbook, Wood as an Engineering Material. Madison, WI: USDA, Forest Product Service, Forest Product Laboratory. Hlm 19.1 - 19.14.

[12] Pranata, Y. A., Simanta, D. (2006). Studi Analisis Beban Dorong untuk Gedung Beton Bertulang. Jurnal Teknik Sipil, 2(1), 235.

[13] Pusat Penelitian dan Pengembangan Permukiman. (2011). Desain Spektra Indonesia. Dipetik Juni 25, 2017, dari puskim.pu.go.id: http://puskim.pu.go.id/Aplikasi/desain_spektra_indonesia_2011/.

[14] Serrano E. (2003). Mechanical Performance and Modelling of Glulam. West Sussex: Jhon Wiley \& Sons, Ltd. 
Penulis Pertama dan Penulis Kedua (jika penulis 2 orang) / Penulis Pertama dkk. (jika penulis lebih dari 2 orang) 